\title{
On Psychological Peculiarities of Atypical Binge-Eating
}

\section{Психологічні аспекти атипового компульсивного переїдання}

\author{
Lesia Lymar \\ Ph.D. in Psychology, Senior \\ Lecturer \\ Леся Лимар \\ кандидат психологічних \\ наук, старший викладач \\ E-mail:lesyalymar@ukr.net \\ orcid.org/0000-0002-9407-1066 \\ Researcher ID : D-3586-2017
}

Bogomolets National Medical

University, Ukraine

34, Peremohy avenue, Kyiv,

Ukraine, 03680
Національний медичний університет ілені

О.О. Боголольия, Україна

просп. Перемоги, 34, м. Київ, Україна, 03680

Original manuscript received May 28, 2018

Revised manuscript accepted October 25, 2018

\begin{abstract}
The article defines the notion of atypical binge eating as a non-systematic consumption of food by a person, in the volumes which exceed his needs in the nutrients, and which consequently leads to obesity, though this condition is not associated with weird nutritional habits or the "peculiar" respectful attitude to the food consuming itself. The author has analyzed numerous Ukrainian and foreign literature sources to conclude that the issue of atypical binge eating hasn't been studied sufficiently, particularly by Ukrainian researchers. The article dwells on the absence of strict definition of the "binge eating" notion, the atypical binge eating being even more unclear to define, as it may be diagnosed according to the person's subjective data on her frequency of binge episodes and the consumed food amount. The author emphasizes double standards of defining binges according to the DSM criteria. The article de-
\end{abstract}


scribes the "binge eating" notion as it was developed from the "night eating» in 1955 until the "binge eating" was included in the DSM-5 in 2013 as a medical term. Due to the performed literature data analysis, the main factors of the atypical binge eating have been defined as follows: the pre-shaped nutritional culture and habits in the society, physical disease, chosen stress management behavioral strategy, food addiction as a method of stress management or self-realization. The following atypical binge eating factor groups have been established: the social-cultural (mindsets, society customs and family habits) and individual ones, which include certain medical-physiological, comorbid psychiatric and psychological causes. The article analyses main approaches to defining the atypical binge eating as an addiction subtype: the psychoanalytical, behavioristic and the gestalt approach. The author concludes on the possible directions of correction within the established factors groups: socialcultural direction, supported by the State: healthy eating promotion, informing population on the nutritional regimen and diet importance, food labeling; and the individual one, which includes personal management of each binging person, with pharmacological, surgical or psychotherapy counselling therapy.

Key words: atypical binge eating, overweight, obesity, correction.

\section{Вступ}

Останнім часом проблема надмірної ваги та пов'язаних із нею розладів харчової поведінки набула особливої актуальності через високі показники ожиріння та пов'язаних із ним проблем, що підтверджується останнім звітом ВООЗ (WHO Survey on BED). Компульсивне переїдання - один із розладів, що призводить до ожиріння, а також пов'язаний із низкою подальших розладів фізичного та психічного здоров'я (Fairburn, 1993). Проблема компульсивного переїдання, зокрема атипового компульсивного переїдання, що носить несистематичний характер і може бути визначене як зловживання їжею, на даний момент вивчена недостатньо, на відміну від таких розладів, як булімія чи анорексія. Визначення психологічних чинників переїдання та їх механізмів розвитку обумовлює можливості корекції цих причин і проведення відповідної роботи з населенням.

Поняття компульсивного переїдання (Binge-eating disorder) аналізували численні вітчизняні (Л. Абсалямо- 
ва, 2014; Т. Смельянцева, 2015; С. Литвин-Кондратюк, 2000; О. Мойзріст, 2009) та іноземні автори (C. Bulik, 2014; De Zwaan, 2004; C. Fairburn, 1993; M. Fichter, 1998; R. Spitzer, 1993; A. Stunkard, 1955; N. Berkman, 2015), зокрема в контексті класичного компульсивного переїдання, булімії й анорексії. Власне, поняття переїдання як розладу одним із перших описав А. Станкард (Stunkard, 1955), відокремивши у 1955 р. поняття «нічного прийому їжі», з подальшим ранковим відмовлянням від їжі. Він же описав ожиріння при компульсивному переїданні та синдром «напихання їжею». У 1980 р. булімія - патологічне переїдання з подальшою відмовою від прийому їжі - була включена до DSM (American Psychiatric Association et al., 1980), Керівництва з діагностики та статистичних класифікацій психічних розладів, тобто офіційно визнана психологічною патологією. У DSM-III-R (зміненому виданні) було визначено нервову булімію як відмову від їжі після раптового переїдання, проте власне проблемі переїдання, без подальшої відмови від їжі, уваги не було приділено. У 1994 р. компульсивне психогенне переїдання було включено до Керівництва з діагностики та статистичних класифікацій психічних розладів DSM-4 (P. Beumont, 1994), де згідно Міжнародної Класифікації Хвороб МКХ 10 патологія отримала код 50.4, EDNOS «переїдання, пов'язане з іншими психологічними розладами: переїдання, спричинене стресовими подіями, втратою, нещасним випадком, народженням дитини...» (American Psychiatry Association et al., 1994).

Останнє видання Керівництва з діагностики та статистичних класифікацій психічних розладів DSM-5 (2013 р.) визначило психогенне переїдання під кодом 307.51 (F 50.8) як так зване «Binge eating disorder» (American Psychiatric Association et al., 2013). Тобто, тільки у 2013 р. компульсивне переїдання було офіційно визнано захворюванням, відтак, проблема переїдання все ще вивчається науковцями. Типове компульсивне переїдання характеризуєть- 
ся систематичним (часто вечірнім) споживанням великої кількості їжі, з подальшими епізодами ранкового сорому, відмови від їжі, причому в осіб, які переїдають, спостерігається занижена самооцінка, напади сорому тощо.

Термін «атипове компульсивне переїдання» вперше вжив С. Фейрбурн (Fairburn, 1993). Автор визначає його як несистематичне вживання великої кількості їжі, з усвідомленням шкоди від цього для власного здоров'я, проте без подальшої відмови від їжі вранці, без спроб дотримуватися суворої дієти надалі.

Проведений аналіз статей і дисертаційних досліджень вітчизняних учених (Л. Абсалямової (Абсалямова, 2014), Т. Вознесенської (Вознесенська, 2009), Т. Смельянцевої (Ємельянцева, 2015), О. Мойзріст (Мойзріст, 2009), I. Нагорної (Нагорна, 2011)) виявив недостатність вивчення проблеми переїдання в Україні саме з психологічної точки зору. Вітчизняні дослідники найчастіше визначають компульсивне переїдання у межах підтипу адикцій.

Численні дослідження іноземних фахівців, які з другої половини XX століття проводили С. Булік (C. Bulik, 2014), Де Ж Кваан (De Zwaan, 2004), С. Фейрбурн (C. Fairburn, 1993), M. Фіхтер (M. Fichter, 1998), К. Кастонгуей (L. Castonguay, 1995), Б. Брюс (В. Bruce, 1992), більше сконцентровані на взаємозв' язку між персональною тривожністю, загальним рівнем тривожності у суспільстві та компульсивним переїданням. Дослідження переїдання проводяться у межaх проекту BOO3 (World Health Organization: Obesity and overweight).

\section{Завдання статті}

Визначити поняття «атипове компульсивне переїдання» на підставі проведеного дослідження літератури, проаналізувати основні підходи до виникнення цього розладу, сформулювати основні чинники розладу, зокрема психологічні, запропонувати механізми їх корекції при роботі 3 населенням. 


\section{Методи дослідження}

У статті використані такі методи: аксіоматичний, в основі якого лежить конструювання теорій за допомогою логічного висновку з аксіом, - для створення універсального теоретико-методологічного конструкту, який дає змогу цілісного розуміння механізмів інформаційного впливу; контекстуальний - для розширення рамок аналізу інформаційного впливу; синергетика як трансдисциплінарний метод, що дозволяє долати парадигмальну множинність існуючих підходів, - для розгляду інформаційного впливу як феномену, що сприяє самоорганізації споживача інформації, групового суб’єкта комунікації, колективного суб’єкта суспільства.

\section{Результати та дискусії}

За даними ВООЗ, у світі кількість показників ожиріння потроїлись із 1975 р. У 2016 р. у понад 1,9 млрд дорослих визначено надмірну вагу, в 650 млн - ожиріння (World Health Organization: Obesity and overweight). Компульсивне переїдання є однією з причин розвитку цього розладу. У DSM-5 компульсивне психогенне переїдання визначається як таке, коли в особи, яка переїдає (Binge-eater), спостерігаються (DSM-5 American Psychiatric Association et al., 2013):

1. Повторення епізодів переїдання: прийом їжі у визначений період часу (наприклад, упродовж двох годин), причому ця кількість їжі перевищує ту, яку люди зазвичай споживають за цей час; а також відчуття втрати контролю у процесі переїдання (особа відчуває, що не може зупинитися або контролювати, скільки вона з'їла).

2. Особа їсть швидше, ніж зазвичай; особа їсть, доки не відчуває дискомфорт через переїдання; особа їсть багато їжі, коли не відчуває голоду; особа їсть наодинці, бо ніяковіє через те, як багато вона їсть; особа відчуває до себе відразу, провину, депресію після переїдання. 
3. Зазвичай, особа засмучена через те, що вона переїдає.

4. Випадки переїдання спостерігаються щонайменше двічі на тиждень упродовж 6 місяців (критерій частоти та тривалості за DSM-IV (American Psychiatry Association et al., 1994)), або щонайменше один раз на тиждень упродовж 3 місяців (критерій частоти та тривалості за DSM-V (American Psychiatric Association et al., 2013)).

5. Переїдання не пов'язане з регулярною невідповідною компенсаторною поведінкою (піст, відмова від їжі, вживання проносних засобів, надмірні фізичні вправи 3 метою втрати ваги).

Окрім цього, низка науковців - Б. Брюс (Bruce, 1992), Де Ӟваан (De Zwaan, 2004), C. Фейрбурн (Fairburn, 1993), M. Фіхтер (Fichter, 1998) зазначає такі ознаки психогенного переїдання: особа ховає їжу від інших у себе в квартирі, в кімнаті; особа обирає певний стиль харчування з визначеними обмеженнями (їжа без цукрів, без білків, вегетаріанство, веганство); особа регулярно дотримується дієти; особа створює власні ритуали прийому їжі; особа краде їжу; особа систематично шукає ознаки зміни власної зовнішності після переїдання.

Отже, спостерігаємо несистемність визначення компульсивного переїдання, адже, на думку автора, вибір стилю харчування без певного виду їжі недоречно порівнювати $з$ переїданням на ніч. Формулювання про «2-годинний період» споживання їжі виключає переїдання, коли особа дивиться серіал і споживає фаст-фуди, систематичне відвідування закладів швидкого харчування та піцерій, хоча споживання такої їжі безпосередньо не належить до переїдання. Невизначеність спостерігається і щодо класифікації ступенів переїдання: DSM-IV не містить класифікації ступенів переїдання (American Psychiatry Association et al., 1994).

У DSM-V розрізняється 4 ступені переїдання: незначне - від 1 до 3 випадків на тиждень, помірне - від 4 до 7 
випадків на тиждень, суворе - від 8 до 13 випадків на тиждень і надмірне - 14 і більше випадків переїдання на тиждень (American Psychiatric Association et al., 2013). Класифікація переїдання створюється зі слів особи, яка переїдає, тобто суб'єктивність частоти й обсягів переїдання значно впливає на класифікацію переїдання.

Розмитість формулювань спостерігаємо і при визначенні поняття «переїдання», не існує чітких критеріїв переїдання чи споживання великої кількості їжі. С. Фейрбурн (Fairburn, 1993), М. Фіхтер (Fichter, 1998), Р. Спітцер (Spitzer, 1992; 1993), М. Вісмен (M. Whisman, 2012), C. Яновський (Yanovski, 1993) визначають компульсивне переїдання як «споживання надмірної кількості їжі», за відсутності визначених критеріїв норми споживання для кожної особи (існують норми споживання за кількістю білків, вуглеводів, ліпідів, проте не сформульовано норми обсягу споживання харчових продуктів), тобто цей показник, здебільшого, носить суб'єктивний характер, за визначенням самого пацієнта, а також «надмірно частий» потяг до споживання їжі, що також має суб'єктивний характер.

Деякі автори визначають переїдання як основну характеристику ожиріння (Yanovski, 1994), коли інші зазначають, що переїдання є тільки неспецифічним зразком харчової поведінки (Marcus, 1992). При невизначеності в культурі країни норми та режиму їжі («повна тарілка, перше чи друге», чітко заведений час споживання їжі тощо) особам украй важко зрозуміти, що вони переїдають.

Іншою ознакою переїдання є психологічні особливості тих, хто переїдає: особливе ставлення до їжі, ритуали споживання їжі, часті розмови про їжу тощо. Проте навіть за відсутності особливого ставлення до їжі й певних ритуалів особа може значно переїдати. Чи можна у такому випадку, коли особа тричі на тиждень споживає ввечері упродовж 30 хвилин перегляду серіалу подвійний набір фаст-фуду 3 надмірною калорійністю, вважати переїданням? За критеріями - ні, проте насправді це переїдання. Також по- 
стає питання: яким чином особи із сімейною історією переїдання та традиціями споживання великих обсягів їжі можуть самостійно помітити, що вони переїдають, коли за їхніми уявленнями обсяг спожитої їжі відповідає нормі? Усе це призводить до викривлення даних поширеності переїдання, оскільки найчастіше проблема визнається лише у разі досягнення ожиріння особами, які переїдають (Castonguay, 1995).

У сучасній літературі немає чітких цифрових критеріїв, за якими можна визначити компульсивне переїдання, не кажучи про атипове компульсивне переїдання. С. Фейрбурн визначає його як несистематичне вживання великих обсягів їжі, без прив'язування до певних продуктів чи певних ритуалів, із набиранням особою зайвої ваги (Fairburn, 1993). Варто зазначити суб’єктивний характер визначення цього явища (обстеженим пропонується самим визначити, чи переїдають вони), у поєднанні з даними медичних досліджень (індекс маси тіла, захворювання ШКТ, пов’язані з переїданням).

Проведений аналіз літератури наводить на думку, що несистематичне компульсивне переїдання є відносним поняттям, яке можливо охарактеризувати так: особа безсистемно споживає значно більший, ніж потребує її організм, об’єм їжі, часто ввечері, часто це «нездорова їжа» (фастфуд, тістечка, жирна їжа, часте запивання великою кількістю алкоголю), що призводить до збільшення показників індексу маси тіла (надмірної ваги чи ожиріння). Цей стан можливо визначати за суб'єктивними свідченнями осіб (коли під час опитування особа визнає, що переїдає більше 3-4 разів на тиждень, причому частота у цьому випадку є відносним показником) і за підвищеним індексом маси тіла (за відсутності в особи інших захворювань, що можуть призводити до цього) у поєднанні з іншими фізіологічними показниками, спричиненими потраплянням в організм надмірної кількості харчових речовин. 
Переїдання можливо охарактеризувати з медико-фізіологічного та психологічного підходів. Фізіологічний підхід до переїдання визначає його як результат надмірного почуття голоду, зумовленого станом ЦНС, активністю харчового центру (гіпоталамо-лімбіко-ретикулокортикального комплексу, латеральних і вентромедіальних ядер гіпоталамуса), який регулює почуття голоду, поведінкові реакції людини та контролює масу тіла (Емельянцева, 2015). Отже, переїдання пов'язане із захворюванням організму (так звана теорія хвороби). У межах фізіологічного підходу варто розглядати переїдання як стан, коморбідний із такими психіатричними захворюваннями, як афективне захворювання, депресивні стани та тривожні розлади (Bruce, 1992).

Згідно психологічного підходу, переїдання можливо визначити як різновид адиктивної (залежної) поведінки. За Ц. Короленко, всі адикції поділяють на хімічні (наприклад, залежність від наркотиків), нехімічні (залежність від азартних ігор) і проміжні, до яких і належить залежність від їжі (Короленко, 2001).

У межах визначення переїдання як різновиду адикцій можливо визначити такі теорії переїдання: теорію особистісних рис, або моральну, коли адикція (залежність) виникає внаслідок сформованих рис особистості, слабкості особистості (відповідальність на особистості); теорію реактивного опору, коли особистість реагує на зміну умов навколишнього середовища, що, на її думку, обмежують певні її права чи свободи, і шляхом вживання речовин (їжі), до яких у неї формується залежність, особистість отримує власну свободу; теорію соціального навчання, згідно з якою залежність особистості від їжі виникає внаслідок оточуючих її умов, в результаті ставлення до їжі в соціумі (їжа - друге щастя, з’їси цукерку - і стає легше).

Також виокремимо симптоматичну теорію (залежність від їжі обумовлена певною причиною та розвивається як реакція особистості на визначену подію, як-то стрес, втра- 
та члена родини, розлучення), психоаналітичну (залежність від їжі сягає своїм корінням у певний період розвитку дитини, за З. Фрейдом, проблеми упродовж оральної стадії розвитку, як-то раннє припинення грудного годування чи взагалі його відсутність, у дорослому віці найчастіше призводять до залежності від їжі) та комплексну теорію, на нашу думку, найповнішу, коли розглядається загальний стан фізичного та психічного здоров'я особи та залежність у ній. Варто також розглянути переїдання як спосіб переживання фрустрації між «Я-ідельним» i «Я-реальним» .

Зауважимо, що залежність від їжі розглядають і в таких підходах: біхевіористичному (поведінкова реакція особистості як спосіб самовиявлення, прояв власної поведінки), гештальт-підході (визначений особистістю гештальт залежності як обрана стратегія, певний штамп у поведінковій реакції, небажання шукати нові способи поведінки, часто пов' язаний з установками в родині й оточенні), організаційному (керування особистістю власними діями та спосіб організації власної діяльності з урахуванням залежності).

Аналіз літератури показав, що більшість осіб, які несистематично переїдають, характеризують себе як «незрілі», скаржаться на численні проблеми в міжособистісних стосунках, схильні до депресивних станів, коли ніщо, крім їжі, їм не покращує настрій (Емельянцева, 2015; МалкинаПых, 2010; Мойзріст, 2009; Вознесенская, 2009). Уранці після епізоду переїдання особи знову виявляють депресивний стан через усвідомлення кількості спожитої їжі та наслідків спожитого, а також через усвідомлення власної провини. Цікаво, що, згідно з дослідженнями С. Булік (Bulik, 2014), жінки й особи, які отримали вищу освіту, виявили більшу схильність до компульсивного переїдання, ніж особи без освіти, що, на думку автора, зумовлено перфекціонізмом, розвинутим упродовж навчання в університеті, а також нездатністю особи керувати своїм життям і досягати мети в інший спосіб, ніж споживання їжі. 
Подібні висновки підтверджують Б. Брюс (Bruce, 1992) та С. Яновський (Yanovski, 1994). Дослідження М. Вісмана показують, що заміжні жінки більш схильні до переїдання, ніж неодружені (Whisman, 2012). Проведений аналіз дав змогу класифікувати основні чинники несистематичного компульсивного переїдання на дві групи.

1. Соціально-культурний чинник. У цьому контексті варто розглядати соціально-культурні чинники на рівні суспільства та соціально-культурні чинники на рівні окремої родини. Соціальне налаштування суспільства, згідно якого їжа - це спосіб вирішення проблем, спосіб покращити настрій, успішність визначається споживанням дорогої їжі. Також до цього чинника відносяться наявність культури споживання їжі та харчові звички нації (споживання їжі у визначений час, споживання сезонної висококалорійної їжі, стандарти споживання їжі за один підхід - так звана норма-порція) (Нагорна, 2011).

Велике значення відіграє сприйняття їжі, що склалося упродовж тривалого історичного періоду, коли для культури країни характерна велика повага до їжі, їжа часто згадується в казках і прислів'ях, відтак, це також сприяє формуванню культури переїдання.

Масштабні рекламні кампанії фаст-фуду, солодких висококалорійних напоїв, шоколадних виробів, які асоціюються з успішним життям, поширеність фаст-фуду в кінотеатрах сприяють популяризації нездорової їжі.

Економічно вища доступність таких продуктів, як хліб, крупи та картопля у поєднанні з харчовими традиціями сприяють підвищенню калорійності дієти населення. Режим роботи в країні, коли робочий день, здебільшого, закінчується о 6-й і особа потрапляє додому не раніше 7-ї години, також сприяє нічному переїданню, особливо у поєднанні з культурною традицією дивитись увечері телевізор (новини, серіали, футбол) і водночас споживати їжу, коли відбувається одночасне «заїдання» стресових подій, які показують по телевізору. 
Соціально-культурний чинник на рівні родини включає ставлення визначеної родини до їжі, сімейні традиції, пов’язані зі споживанням їжі та переїданням, схильність членів родини до адиктивної поведінки тощо. На межі соціального й особистісного чинників знаходяться сімейні звички харчування та сімейна схильність до атипового несистематичного переїдання.

2. Особистісний чинник. Переїдання особи може бути зумовлено захворюванням (дисбалансом в організмі), а також психологічними проблемами особи. Високий рівень особистісної тривожності, який може відображати рівень загальної суспільної тривожності, сприяє переїданню. Особа, яка переїдає, повністю несе відповідальність за переїдання. Причиною переїдання можуть бути стрес, надмірна втома, фізичне захворювання. Здебільшого, особистісними чинниками психологічно обумовленого атипового переїдання є відсутність режиму дня й установлених харчових правил і звичок, стресові ситуації або недостатність позитивних емоцій у житті особи, недостатність задоволення, егоїзм особи, рання психологічна травма тощо. Для цього чинника характерна так звана «слабкість» характеру, адже особа, яка переїдає, усвідомлює (чи, навпаки, агресивно заперечує) те, що її харчова звичка не є нормальною та шкодить здоров'ю, проте продовжує це робити через механізм утвореної залежності. Високий рівень тривожності також може виступати чинником переїдання.

Отже, маємо справу з психологічними проблемами власне особи, яка переїдає: відсутність самоідентифікації та дисципліни, сильне відчуття провини і намагання підсвідомо «покарати себе», або заміщення реальної ситуації ситуацією за столом, коли особа дозволяє собі все (M. Marcus, 1992).

Відповідно до окреслених двох груп, ми пропонуємо такі засоби, спрямовані на корекцію компульсивного несистематичного переїдання: роботу власне з особою (корекційну та пропагандистську), а також роботу на рівні соціу- 
му. На рівні соціуму необхідно проводити численні освітні заходи з пропаганди харчової культури (пояснення про типи їжі, потреби організму в їжі, необхідний час для прийняття їжі, наслідки переїдання, харчову норму, ускладнення зі здоров'ям унаслідок переїдання).

У межах соціального компонента варто не просто проводити роз'яснювальну роботу, але й активно залучати Міністерство охорони здоров'я, сприяти пропаганді здорового харчування в засобах мас-медіа, розробляти маркування висококалорійної їжі тощо. На нашу думку, варто обмежити доступність придбання нездорової їжі для дітей до досягнення ними певного вікового періоду. Здатність медичного та психологічного персоналу на власному прикладі демонструвати дотримання стандартів здорового харчування сприятиме пропаганді здорового харчування. Варто зазначити, що невизнання проблеми переїдання та надмірної ваги (коли у мас-медіа висвітлюється тільки здорове харчування, актори та ведучі винятково відповідають стандартам ваги) так само є соціальною проблемою, яка може призводити до об’їдання.

На рівні особистісного компонента необхідно з кожною особою, яка переїдає, проводити визначення: чи є переїдання наслідком гормонального дисбалансу в організмі, чи необхідне лікування препаратами, чи переїдання має більше психологічне підгрунтя (високий рівень тривожності, психологічні травми, стрес), і відповідно проводити корекційну роботу: особисті консультації чи створення терапевтичних груп для тих, хто переїдає.

На жаль, у культурі нашої країни досі спостерігається упереджене ставлення до психологів і психотерапевтів, а також до групової терапії, отже, індивідуальна робота психолога з особами, які переїдають, може презентувати численні проблеми через несприйняття психолога. Іншою альтернативою переїдання (скоріше, наслідків переїдання й ожиріння) є рармакологічне (вживання антидепресантів при визначених психологічних чинниках переїдання, 
які більше мають ефект плацебо) та хірургічне лікування (Whisman, 2012).

\section{Висновки}

На основі проведеного аналізу літератури визначено атипове компульсивне переїдання як різновид компульсивного переїдання: несистематичне споживання (найчастіше на ніч) великої кількості їжі, суб'єктивно визначене особою, яке поступово призводить до збільшення індексу маси тіла.

Аналіз різноманітних підходів до переїдання (медичного, психоаналітичного, біхевіористичного, гештальтпідходу, організаційного) показав, що переїдання може мати медичні (наприклад, порушення гормонального балансу) та психологічні (стрес, попередні психологічні травми) причини. Основні чинники переїдання, визначені автором, поділено на дві групи: соціально-культурні на рівні суспільства та родини (позитивний образ їжі, уявлення про їжу як спосіб покращення життя, важкі соціальні умови життя, сімейні традиції споживання їжі) й індивідуальні (захворювання особи, в тому числі коморбідні психіатричні патології, адитивна поведінка особи, низький рівень відповідальності особи, сформована звичка «заїдати» проблеми чи знижувати шляхом «заїдання» рівень особистої тривожності).

Зазначене, на думку автора, актуалізує потребу пропаганди здорового харчування та корекції звичок компульсивного переїдання на соціально-культурному (пропаганда здорового харчування в засобах масової інформації, проведення освітніх харчових кампаній, маркування нездорової їжі, формування культури споживання здорової їжі) й індивідуальному (визначення фізичних і психологічних чинників переїдання та їх фармакологічна, хірургічна чи психологічна корекція, зокрема створення психологічних груп підтримки й індивідуальне психотерапевтичне консультування осіб, які переїдають) рівнях. 
Через високу поширеність переїдання та ожиріння в усіх країнах вважаємо перспективним подальше дослідження психологічних чинників атипового компульсивного переїдання та дослідження можливих методів психологічної корекції переїдання у молоді України.

\section{Література}

Абсалямова Л.М. Розлади та порушення харчової поведінки особистості. Проблели сучасноӥ психологї̈: Збірник наукових праць Кам'янець-Подільського національного ун-ту імені І. Огієнка, Інституту психології імені Г.С. Костюка АПН України. Вип. 25. Кам'янець-Подільський : Аксіома, 2014. С. 19-33.

Вознесенская Т.Г. Расстройства пищевого поведения при ожирении и их коррекция. Фармакология. 2009. № 12. С. 91-94.

Деньгина Л.А. Анализ проблематики качественных исследований личностей с пищевой зависимостью. Российская академия образования «Международная академия акмеологических наук», центр акмеологических исследований. 2014.

Емельянцева Т.А. Потенциальные механизмы, лежащие в основе ассоциации между ожирением и психическими расстройствами у детей. XVI Съезд психиатров России. Материалы Всероссийской научно-практической конференции с международным участием "Психиатрия на этапах реформ: проблемы и перспективы", 2015. С. 192-193.

Короленко Ц.П., Дмитриева Н.В. Психосоциальная аддиктология. Новосибирск : Олсиб, 2001. 251 с.

Литвин-Кіндратюк С.Д. Харчова активність особистості: традиційні й інноваційні стратегії. Збірник наукових пращь: філософія, соціологія, психологія. Івано-Франківськ : Вид-во «Плай» Прикарпатського ун-ту, 2000. Вип. 5, Ч. 1. С. 160- 165.

Малкина-Пых И.Г. Перфекционизм и удовлетворенность образом тела в структуре личности пациентов с нарушениями пищевого поведения и алиментарным ожирением. Экология человека. 2010. № 1. С. 21-27.

Мойзріст О.М. Види порушень харчової поведінки. Проблеми сучасної психології: Збірник наукових праць Кал'янець-Подільського національного ун-ту імені I. Огієнка, Інституту психології ілені Г.С. Костюка АПН України. Кам'янець-Подільський національний університет імені Івана Огієнка, Інститут психології імені Г.С. Костюка АПН України, 2009. Вип. 6, Т. 6. С. 85-94.

Нагорна I.С. Ожиріння як соціальна проблема сучасної молоді. Сучасне українське студентство, проблели та иіннісні орієнтацї̈ : Ма- 
теріали V Всеукраїнської науково-практичної конференції лолодих вчених. Хмельницький : ХІCT, 2011. Т. 5. С. 182-185.

American Psychiatric Association. (1981). Diagnostic and Statistical Manual of Mental Disorders. DSM-III. Washigton, DC : American Psychiatric Association.

American Psychiatric Association. (1994). Diagnostic and Statistical Manual of Mental Disorders DSM-IV. Washigton, DC : American Psychiatric Association.

American Psychiatric Association. (2013). Diagnostic and statistical manual of mental disorders (DSM-5®). American Psychiatric Pub.

Berkman, N.D., Brownley, K.A., \& Peat, C.M., et al. (2015). Management and Outcomes of Binge-Eating Disorder. Rockville (MD) : Agency for Healthcare Research and Quality (US). (Comparative Effectiveness Reviews, № 160). Retrieved from https://www.ncbi.nlm.nih.gov/ books/NBK338301/

Beumont, P.J., Garner, D., \& Touyz, S.W. (1994). Comments on the proposed criteria for eating disorders in DSM IV. European Eating Disorders Review, 2 (2), 63-75.

Bruce, B., \& Agras, W.S. (1992). Binge eating in females: A populationbased investigation. International Journal of Eating Disorders, $12(4), 365-373$.

Bulik, C.M. (2014). Developmental disruption by binge-eating disorder and bulimia nervosa: critical windows for detection and intervention. Epidemiology and psychiatric sciences, 23 (1), 43-45.

Castonguay, L.G., Eldredge, K.L., \& Agras, W.S. (1995). Binge eating disorder: Current state and future directions. Clinical Psychology Review, 15 (8), 865-890.

DeZwaan, M., Mitchell, J.E.,Swan-Kremeier,L., McGregor, T., Howell, M.L., Roerig, J.L., \& Crosby, R.D. (2004). A comparison of different methods of assessing the features of eating disorders in post-gastric bypass patients: a pilot study. European Eating Disorders Review: The Profes sional Journal of the Eating Disorders Association, 12 (6), 380-386.

Fairburn, C.G., Wilson, G.T., \& Schleimer, K. (1993). Binge eating: Nature, assessment, and treatment. New York : Guilford Press, 317-360.

Fichter, M.M., Herpertz, S., Quadflieg, N., \& Herpertz-Dahlmann, B. (1998). Structured interview for anorexic and bulimic disorders for DSM-IV and ICD-10: Updated (third) revision. International Journal of Eating Disorders, 24 (3), 227-249.

Marcus, M.D., Smith, D., Santelli, R., \& Kaye, W. (1992). Characterization of eating disordered behavior in obese binge eaters. International Journal of Eating Disorders, 12 (3), 249-255.

Spitzer, R.L., Devlin, M.J., Walsh, B.T., Hasin, D., Wing, R., Marcus, M.D., \& Mitchell, J. (1991). Binge eating disorder: To be or not to be in DSM-IV. International Journal of Eating Disorders, 10 (6), 627-629. 
Spitzer, R.L., Yanovski, S., Wadden, T., Wing, R., Marcus, M.D., Stunkard, A., \& Horne, R.L. (1993). Binge eating disorder: its further validation in a multisite study. International Journal of Eating Disorders, 13 (2), 137-153.

Stunkard, A.J., Grace, W.J., \& Wolff, H.G. (1955). The night-eating syndrome: a pattern of food intake among certain obese patients. The American journal of medicine, 19 (1), 78-86.

Whisman, M.A., Dementyeva, A., Baucom, D.H., \& Bulik, C.M. (2012). Marital functioning and binge eating disorder in married women. International Journal of Eating Disorders, 45 (3), 385-389.

World Health Organization: Obesity and overweight. Retrieved from http://www.who.int/news-room/fact-sheets/detail/obesity-andoverweight/

World Health Organization (WHO) Survey on BED. Retrieved from https:// bedaonline.com/world-health-organization-survey-bed/

Yanovski, S.Z., Nelson, J.E., Dubbert, B.K., \& Spitzer, R.L. (1993). Association of binge eating disorder and psychiatric comorbidity in obese subjects. The American journal of psychiatry, 150 (10), 147.

Yanovski, S.Z., \& Sebring, N.G. (1994). Recorded food intake of obese women with binge eating disorder before and after weight loss. International Journal of Eating Disorders, 15 (2), 135-150.

\section{References}

Absalyamova, L.M. (2014). Rozlady ta porushennia kharchovoi povedinky osobystosti [Disorders of nutritional behavior of a person]. Problemy suchasnoi psykholohii: Zbirnyk naukovykh prats Kamianets-Podilskoho natsionalnoho universytetu im. I. Ohiienka, Instytutu psykholohii imeni H.S. Kostiuka APN Ukrainy - The Collection of Research Papers of Kamianets-Podilskyi National University named after I. Ohienko and Institute of Psychology named after G.S. Kostiuk, 25, 19-33 [in Ukrainian].

Voznesenskaja, T.H. (2009). Rasstrojstva pishchevogo povedenyja pri ozhirenii i ih korrekcija [Disorders of alimentary behavior associated with obesity and its correction]. Farmateka, 12, 91-94 [in Russian].

Dengina, L.A (2014). Analysis of quality studies of people with nutritional dependence. Russian Academy of Education «International academy of acmeological sciences». Center of acmeological studies [in Russian].

Emeljanceva, T.A., Solnceva, A.V., Zagrebaeva, O.Yu., \& Aksenova, E.A. (2015). Potencialnye mehanizmy, lezhashchie v osnove associacii mezhdu ozhireniem i psihicheskimi rasstrojstvami u detej [Potential mechanisms, treatment and basic associations between obesity and psychological diseases in children]. Materialy XVI Sjezda psihiatrov 
Rossii. Vserossijskaja nauchno-prakticheskaja konferentcija s mezhdunarodnym uchastiem - Materials of the XVI Meeting of Russian Psychiatrists, All-Russian scientific-practical conference with international participation [in Russian].

Korolenko, T.P., \& Dmitrieva, N.V. (2001). Psihosocialnaja addiktologija [Psychosocial addictology]. Novosibirsk : Olsib [in Russian].

Lytvyn-Kindratiuk, S.D. (2000). Kharchova aktyvnist osobystosti: tradytsiini i innovatsiini stratehii [Nutritional activity of a person: traditional and innovative strategies]. Ivano-Frankivsk : Vyd-vo «Plai» Prykarpatckoho u-tu, 5, 160-165 [in Ukrainian].

Malkina-Pyh, I.G. (2010). Perfekcionizm i udovletvorennost obrazom tela v strukture lichnosti pacientov s narushenijami pishchevogo povedenija i alimentarnym ozhireniem [Perfectionism and satisfaction with the body image in the personality structure of patients with alimentary behavioral disorders and obesity]. Ekologiya chelovekaEcology of a Human, 1 [in Russian].

Moizrist, O.M. (2009). Vydy porushen kharchovoi povedinky [Types of violating nutritional behavior]. Problemy suchasnoi psykholohii: Zbirnyk naukovykh prats Kamianets-Podilskoho natsionalnoho universytetu im. I. Ohiienka, Instytutu psykholohii imeni H.S. Kostiuka APN Ukrainy - The Collection of Research Papers of KamianetsPodilskyi National University named after I. Ohienko and Institute of Psychology named after G.S. Kostiuk, 6 (6), 85-94 [in Ukrainian].

Nahorna, I.S. (2011). Ozhyrinnia yak sotsialna problema suchasnoi molodi [Obesity as social problem of the youth]. Materialy 5 Vseukraiinskoi naukovo-praktychnoi konferencii-Proceeding of the $5^{\text {th }}$ All-Ukrainian Scientific-Practical conference [in Ukrainian].

American Psychiatric Association. (1981). Diagnostic and Statistical Manual of Mental Disorders. DSM-III. Washigton, DC : American Psychiatric Association.

American Psychiatric Association. (1994). Diagnostic and Statistical Manual of Mental Disorders DSM-IV. Washigton, DC : American Psychiatric Association.

American Psychiatric Association. (2013). Diagnostic and statistical manual of mental disorders (DSM-5®). American Psychiatric Pub.

Berkman, N.D., Brownley, K.A., \& Peat, C.M., et al. (2015). Management and Outcomes of Binge-Eating Disorder. Rockville (MD) : Agency for Healthcare Research and Quality (US). (Comparative Effectiveness Reviews, № 160). Retrieved from https://www.ncbi.nlm.nih.gov/ books/NBK338301/

Beumont, P.J., Garner, D., \& Touyz, S.W. (1994). Comments on the proposed criteria for eating disorders in DSM IV. European Eating Disorders Review, 2 (2), 63-75. 
Bruce, B., \& Agras, W.S. (1992). Binge eating in females: A populationbased investigation. International Journal of Eating Disorders, $12(4), 365-373$.

Bulik, C.M. (2014). Developmental disruption by binge-eating disorder and bulimia nervosa: critical windows for detection and intervention. Epidemiology and psychiatric sciences, 23 (1), 43-45.

Castonguay, L.G., Eldredge, K.L., \& Agras, W.S. (1995). Binge eating disorder: Current state and future directions. Clinical Psychology Review, $15(8), 865-890$.

De Zwaan, M., Mitchell, J.E., Swan-Kremeier, L., McGregor, T., Howell, M.L., Roerig, J.L., \& Crosby, R.D. (2004). A comparison of different methods of assessing the features of eating disorders in post-gastric bypass patients: a pilot study. European Eating Disorders Review: The Professional Journal of the Eating Disorders Association, 12 (6), 380-386.

Fairburn, C.G., Wilson, G.T., \& Schleimer, K. (1993). Binge eating: Nature, assessment, and treatment. New York : Guilford Press, 317-360.

Fichter, M.M., Herpertz, S., Quadflieg, N., \& Herpertz-Dahlmann, B. (1998). Structured interview for anorexic and bulimic disorders for DSM-IV and ICD-10: Updated (third) revision. International Journal of Eating Disorders, 24 (3), 227-249.

Marcus, M.D., Smith, D., Santelli, R., \& Kaye, W. (1992). Characterization of eating disordered behavior in obese binge eaters. International Journal of Eating Disorders, 12 (3), 249-255.

Spitzer, R.L., Devlin, M.J., Walsh, B.T., Hasin, D., Wing, R., Marcus, M.D., \& Mitchell, J. (1991). Binge eating disorder: To be or not to be in DSM-IV. International Journal of Eating Disorders, 10 (6), 627-629.

Spitzer, R.L., Yanovski, S., Wadden, T., Wing, R., Marcus, M.D., Stunkard, A., \& Horne, R.L. (1993). Binge eating disorder: its further validation in a multisite study. International Journal of Eating Disorders, 13 (2), 137-153.

Stunkard, A.J., Grace, W.J., \& Wolff, H.G. (1955). The night-eating syndrome: a pattern of food intake among certain obese patients. The American journal of medicine, 19 (1), 78-86.

Whisman, M.A., Dementyeva, A., Baucom, D.H., \& Bulik, C.M. (2012). Marital functioning and binge eating disorder in married women. International Journal of Eating Disorders, 45 (3), 385-389.

World Health Organization: Obesity and overweight. Retrieved from http://www.who.int/news-room/fact-sheets/detail/obesity-andoverweight/

World Health Organization (WHO) Survey on BED. Retrieved from https:// bedaonline.com/world-health-organization-survey-bed/ 
Yanovski, S.Z., Nelson, J.E., Dubbert, B.K., \& Spitzer, R.L. (1993). Association of binge eating disorder and psychiatric comorbidity in obese subjects. The American journal of psychiatry, 150 (10), 147.

Yanovski, S.Z., \& Sebring, N.G. (1994). Recorded food intake of obese women with binge eating disorder before and after weight loss. International Journal of Eating Disorders, 15 (2), 135-150.

\section{АНОТАЦІЯ}

У статті визначено поняття "атипове компульсивне переїдання» як несистематичне вживання особою їжі в обсягах, що перевищують ії потреби в харчових речовинах, і яке призводить до ожиріння, за відсутності дивних харчових звичок чи особливого ставлення до процесу споживання їжі. Проведено аналіз вітчизняної та зарубіжної літератури, який показав недостатню вивченість проблеми атипового компульсивного переїдання, зокрема вітчизняними фахівцями. Показано нечіткість визначення поняття компульсивного переїдання, зокрема атипового, яке можливе лище за суб'єктивними показниками особи щодо обсягів і частоти переїдання, а також показано неоднозначність трактування визначення переїдання за критеріями DSM.

У статті описано етапи розвитку поняття «компульсивне переїдання», від згадування “нічного переїдання» у 1955 р. до внесення поняття компульсивного переїдання до DSM-5 у 2013 р. На підставі аналізу літератури визначено основні чинники атипового компульсивного переїдання: сформована культура харчування в соціумі чи родині, фізичне захворювання, обраний спосіб харчової поведінки при стресі, адикція до їжі як засіб подолання стресових ситуацій чи самоствердження. Визначено такі групи чинників атипового компульсивного переїдання: соціально-культурні (настанови, звичаї на рівні суспільства та родини) й індивідуальні, серед яких виокремлені медико-фізіологічні, коморбідні психіатричні та психологічні. Проаналізовано основні підходи до визначення атипового компульсивного переїдання як різновиду адикції: психоаналітичний, біхевіористичний, гештальт-підхід. Зроблено висновок щодо можливих напрямків корекції на рівні встановлених чинників: соціально-культурного, на рівні держави, як-то пропаганда здорової їжі, інформування населення про важливість режиму харчування, маркування їжі, й індивідуального, який включає в себе роботу з кожною окремо взятою особою та фрармакологічну чи хірургічну терапію, а також психологічне терапевтичне консультування.

Ключові слова: атипове компульсивне переїдання, ожиріння, харчові звички, корекція. 
Лымарь Леся. Психологические аспекты атипичного компульсивного переедания

\section{АННОТАЦИЯ}

В статье определено понятие атипичного компульсивного переедания как несистематическое употребление особой еды в объемах, которые превышают ее потребности в пищевых веществах, что приводит к ожирению, при отсутствии странных пищевых привычек или особенного отношения к процессу употребления еды. Проведен анализ украинской и зарубежной литературы, который показал недостаточную изученность проблемы атипичного компульсивного переедания, в частности отечественными специалистами. Показано отсутствие четкости в определении понятия "компульсивное переедание», в частности атипичного, которое возможно только благодаря субъективным показаниям личности относительно объемов и частоты переедания, а также показана неоднозначность трактования переедания по критериям DSM.

В статье описаны этапы развития понятия «компульсивное переедание», от упоминания "ночного переедания» в 1955 г. до внесения понятия компульсивного переедания в DSM-5 в 2013 г. На основании анализа литературы определены основные факторы атипичного компульсивного переедания: сформированная культура питания в социуме или в семье, физическое заболевание личности, выбранный способ пищевого поведения при стрессе, аддикция к еде как способ преодоления стрессовых ситуаций или самоутверждения. Определены следующие группы факторов атипичного компульсивного переедания: социальнокультурные (установки, обычаи на уровне общества или отдельной семьи) и индивидуальные, среди которых выделены медико-физиологические, коморбидные психиатрические и психологические. Проанализированы основные подходы к определению атипичного компульсивного переедания как разновидности аддикции: психоаналитический, бихевиористический, гештальт-подход. Сделан вывод относительно возможных направлений коррекции на уровне установленных факторов: социально-культурного, на уровне государства, как пропаганда здорового питания, информирование населения о значении режима питания, маркировка еды, и также индивидуального, который включает работу с каждым отдельно взятым человеком, фрармакологчческую или хирургическую терапию и психологическое индивидуальное консультирование.

Ключевые слова: атипичное компульсивное переедание, ожирение, пищевые привычки, коррекция. 